\title{
12 \\ Assessing the Economic and Environmental Impacts of Conservation Technologies: A Farm-level Bioeconomic Modelling Approach
}

\author{
B. Shiferaw ${ }^{1}$ and S.T. Holden ${ }^{2}$ \\ 1 International Crops Research Institute for the Semi-Arid Tropics (ICRISAT), \\ Nairobi, Kenya \\ 2 Agricultural University of Norway, Ås, Norway
}

\section{Introduction}

Along with degradation of the productive resource base, widespread poverty and population growth are major concerns for sustainable intensification and agricultural development in many poor regions of the world. The relationship between population pressure, poverty and environmental degradation has been a subject of debate and controversies for many years, with an upswing in the debate over the last 30 years (Boserup, 1965; Cleaver and Schreiber, 1994; Tiffen et al., 1994; Grepperud, 1996; Templeton and Scherr, 1999). Earlier studies on technology choice among smallholders in Ethiopia found that low or negative initial returns to conservation technologies could undermine investments in such practices (Shiferaw and Holden, 1998). Some evidence indicated that population pressure, poverty and land scarcity may even encourage removal of conservation structures (that occupy productive lands) introduced in the past through food-for-work programmes.

Although the empirical evidence is mixed and less conclusive (Templeton and Scherr, 1999), there is emerging consensus on the potential nexus between population density, poverty and land degradation in some less-favoured areas where poverty is associated with poor policies, and lack of access to markets and improved technologies (Reardon and Vosti, 1995; Heath and Binswanger, 1996). Under such conditions, poor land users often lack the wherewithal to invest in sustainability-enhancing options and could be caught up in a selfreinforcing nexus that may lead to worsening poverty and resource degradation. However, significant research and development effort is directed towards evolving options for improved natural resource management (NRM) to enhance the productivity and sustainability of production systems. Nevertheless, the basic question remains about the potential of technological and policy options to lift the poor out of poverty, and to what extent these options could 
actually contribute to sustaining the resource base and livelihoods under conditions of high population density and high risk of land degradation.

Bioeconomic models are suited to evaluating the potential impact of new technologies and policy options on rural livelihoods and the environment (resource conditions) at different temporal and spatial scales (Holden, Chapter 8 , this volume). The integration of biophysical and socio-economic conditions into the local economy is an enhancement of earlier econometric approaches, since it allows more-precise simulation of household investment decisions and simultaneous assessment of the welfare and environmental impacts in a dynamic setting - a more suitable approach to assessing NRM impacts. The objective of this chapter is to illustrate how a multiperiod bioeconomic household-level model, in which changes in resource quality have feedback effects on future land productivity, can be used to explore the economic and environmental impacts of NRM technologies and policies. This model is used to test the influence of land scarcity and asset poverty (e.g. oxen and labour) on incentives to undertake sustainability investments. The integration of agroecological and socio-economic information has provided useful insights regarding the potential of alternative policy instruments and the impacts of new technologies. The model incorporates important features of the biophysical system and its dynamics along with market characteristics in the rural economy. The choice of crop and livestock production activities and NRM technology investments are jointly determined. The model is developed in Generalised Algebraic Modelling System (GAMS) using data from Andit Tid, in the central highlands of Ethiopia, an area inhabited by poor smallholder farmers and characterised by high population density, rugged topography, steep slopes, and severe problems of soil degradation.

The results show how land scarcity could drive conservation investments, while poverty in vital assets such as oxen and labour could deter investments in land and water management. The welfare and environmental impacts are very modest but are highest when the conservation technology does not reduce short-term crop yields. Otherwise, the level of adoption of these technologies and their effects on poverty and soil degradation are significantly reduced even when family labour is not limiting. This contributes to worsening the conditions of the poor and continued degradation of the resource base. For credit-constrained households the increased fertiliser use associated with improved credit availability may substitute for conservation effort. The following part of the chapter offers an overview of the case study area and important biophysical and socio-economic aspects included in the model, then the basic structure of the bioeconomic model is presented. This is followed by presentation and discussion of the simulation results. The final part highlights the major findings and policy implications.

\section{The Biophysical and Socio-economic System}

The study area (Andit Tid) is located in North Shewa, in the central highlands of Ethiopia, approximately $60 \mathrm{~km}$ north of Debre Berhan, along the main road 
from Addis Ababa. This implies that market access is fairly good. The area is characterised as a low-potential, cereal-livestock zone and suffers from severe soil degradation. Given the high altitudes, the land falls in two altitude zones: Dega zone (<3200 $\mathrm{m}$ asl) and Wurch zone (>3200 $\mathrm{m}$ asl). There are two distinct rainfall and growing seasons, the Meher (June-December, $1056.8 \mathrm{~mm}$ rainfall), and the Belg season (January-May, $315.4 \mathrm{~mm}$ rainfall).

Barley is the main crop, followed by wheat, horse bean, and field peas. Lentils and linseeds are also commonly grown. The cropping pattern depends on the local agroclimatic zone (see Table 12.1). Crop production mainly depends on organic fertilisers, while the use of mineral fertilisers is limited by lack of credit and the low profitability of applying it to some crops. Most of the production takes place in the low altitude zone but barley is grown also in the higher altitude zone in the Belg season. The major crops during the main growing season (the Meher) are barley, wheat, faba beans, field peas and lentils, in the low-altitude zone. In the Belg season, barley is grown in the high altitude zone, and lentils and field peas in the low altitude zone. Droughts are not common during the Meher season but can occur in the Belg season. Hailstorms and frost may damage crops during the Meher season.

Table 12.1. Crops grown in the different seasons and local agroclimatic zones.

\begin{tabular}{lll}
\hline \multirow{2}{*}{ Season } & \multicolumn{2}{c}{ Cropping zone } \\
\cline { 2 - 3 } Main season (Meher) & $\begin{array}{l}\text { Larley, wheat, faba beans, } \\
\text { field peas, lentils, linseed }\end{array}$ & High altitude \\
Short-rainy season $($ Belg) & Field peas, lentils & Barley \\
\hline
\end{tabular}

The two dominant soil types are Andosols and Regosols. Andosols are dominant in the high-altitude zone while Regosols are common in the lower-lying areas. The Regosols are the most important and intensively cultivated soils. Andosols are mainly used to grow barley and are relatively rich in organic matter. Steep slopes and intensive cultivation increase the risk of soil degradation. An estimated $75 \%$ of the land area is steeply sloped $(>25 \%)$. Soil erosion rates are very high and an estimated $21 \%$ of the agricultural land has shallow soils $(<30 \mathrm{~cm})$ and 48\% medium-deep $(30-60 \mathrm{~cm})$ soil (Yohannes, 1989).

Cattle and sheep are the predominant types of livestock but goats, equines and chickens are also common. There are strong crop-livestock interactions in the system. Crop residues are typically used as animal fodder. Oxen provide traction power to cultivate land and thresh crops. Animal manure is used to enhance soil fertility and for fuel. Fodder shortage is a constraint to livestock production. High population density and land scarcity increase competition between crop and livestock production. Sale of small stock (sheep, goats and chickens) complements both household consumption and crop-production activities. 
Some conservation technologies were introduced through food-for-work programmes in the early 1980s. With the termination of programme benefits in the early 1990s, farmers have been selectively removing soil conservation structures from their plots (Shiferaw and Holden, 1998). The removal seems to be accelerated when structures occupy productive land and increase land scarcity, or when they do not contribute to increasing short-term yields. How poverty affects this process and the potential economic and environmental impacts from such NRM investments are not well understood. Farm households possess usufruct rights to land. Following the land reforms of 1975 and frequent land redistributions thereafter, landlessness is uncommon, and land is fairly distributed according to family size (see Table 12.2). This means that livestock wealth is often a better indicator of household wealth and wealth differentiation. The oxen rental market is underdeveloped (Holden and Shiferaw, 2004) and ownership of traction power is an important asset that determines crop income. When the necessary traction power is lacking and rental markets are imperfect, land ownership by itself may not necessarily translate into better living conditions for the household. Typically, households lacking traction power either rent out land to households with two or more oxen, or depend on relatives with oxen to cultivate their lands. Hence, local communities often use oxen ownership as a wealth indicator. Therefore oxen ownership along with farmland and family labour endowments were used as proxy indicators for household poverty. Future work will need to extend this through use of other more-relevant poverty indicators.

Production remains largely subsistence based. The small towns in the vicinity, inhabited mainly by local traders, serve as markets in the area. Owing to the difficult terrain, there are significant transportation costs to some of the accessible output markets in the area. Farm-gate prices are adjusted for such transaction costs based on local estimates. Some markets for labour, land and livestock exist within the village or in the nearby towns. The labour market is largely inactive, but the local wage rate varies seasonally depending on local demand. Labour may be hired in cash, in kind (fixed output share) or in exchange for traction power. Formal institutional credit is largely unavailable. Hence, the basic model does not include credit, but this assumption was relaxed to assess the effect of credit policy on welfare and sustainability investments. Off-farm income options are mainly limited to local agricultural wages and self-employment in petty trade within the vicinity.

Along with biophysical and experimental data collected by the Soil Conservation Research Project (SCRP), socio-economic data mainly collected in 1994 and complemented in 1998 were used to formulate and develop the model. The availability of on-site biophysical and socio-economic data made it possible to assess technology and policy impacts using a multi-period bioeconomic model. In 1994, about $26 \%$ of the households had no oxen, $15 \%$ had one ox, and $56 \%$ had two oxen. Less than $5 \%$ of households were landless, mainly young families awaiting land allocation by the State. Table 12.2 shows the basic characteristics and resource endowments of the different household groups. For better simulation of the biophysical system and variations in land quality, land was classified into eight different soil depth and slope classes (Table 12.3 and Fig. 12.1). 
Table 12.2. Basic farm household characteristics in Andit Tid, 1994.

\begin{tabular}{lcccc}
\hline & \multicolumn{3}{c}{ Household type $^{\mathrm{a}}$} \\
\cline { 2 - 4 } Variables & No ox & One ox & Two+ oxen & Average \\
\hline Family size & 2.80 & 5.80 & 7.20 & 6.10 \\
Consumer units & 2.60 & 5.17 & 6.58 & 5.55 \\
Labour units & 1.53 & 2.78 & 3.98 & 3.23 \\
Own farm size (Timad) & 5.55 & 7.68 & 11.00 & 9.05 \\
Operated crop area & 3.30 & 5.08 & 8.84 & 6.73 \\
Own cultivated area & 3.00 & 4.79 & 7.80 & 6.07 \\
Rented-in land & 0.30 & 0.28 & 1.04 & 0.66 \\
Rented-out land & 1.55 & 0.18 & 0.10 & 0.31 \\
Tropical livestock units (TLU) & 1.45 & 3.52 & 7.10 & 5.10 \\
Oxen & 0 & 1.00 & 2.30 & 1.53 \\
\hline
\end{tabular}

${ }^{a}$ The sample size was 10 households with no oxen, 30 households with one ox, 40 households with two or more oxen.

${ }^{\mathrm{b}}$ Land areas are measured in Timad, approximately 0.25 ha.

Table 12.3. Land area (in Timad) by farm household category, soil type, soil depth and slope classes.

\begin{tabular}{llccccc}
\hline & & & & & \multicolumn{3}{c}{ Household category } \\
\cline { 6 - 7 } Soil type & Codes & $\begin{array}{c}\text { Soil depth } \\
\text { class (cm) }\end{array}$ & $\begin{array}{c}\text { Slope } \\
\text { class (\%) }\end{array}$ & No ox & One ox & Two+ oxen \\
\hline Andosols (A) & & All & All & 2.03 & 2.82 & 4.02 \\
& A0-30 cm (1) & $0-30$ & $0-20$ & 0.91 & 1.26 & 1.80 \\
& A30-60 cm & $30-60$ & $0-20$ & 0.57 & 0.78 & 1.12 \\
& A $>60 \mathrm{~cm}$ & $>60$ & $0-20$ & 0.32 & 0.44 & 0.63 \\
& A0-30 cm (2) & $0-30$ & $>20$ & 0.24 & 0.33 & 0.48 \\
Regosols (R) & & All & All & 3.52 & 4.88 & 6.98 \\
& R0-30 cm (1) & $0-30$ & $0-20$ & 1.62 & 2.25 & 3.21 \\
& R30-60 cm & $30-60$ & $0-20$ & 0.86 & 1.19 & 1.69 \\
& R $>60 \mathrm{~cm}$ & $>60$ & $0-20$ & 0.31 & 0.44 & 0.62 \\
& R0-30 cm (2) & $0-30$ & $>20$ & 0.73 & 1.01 & 1.44 \\
\hline
\end{tabular}




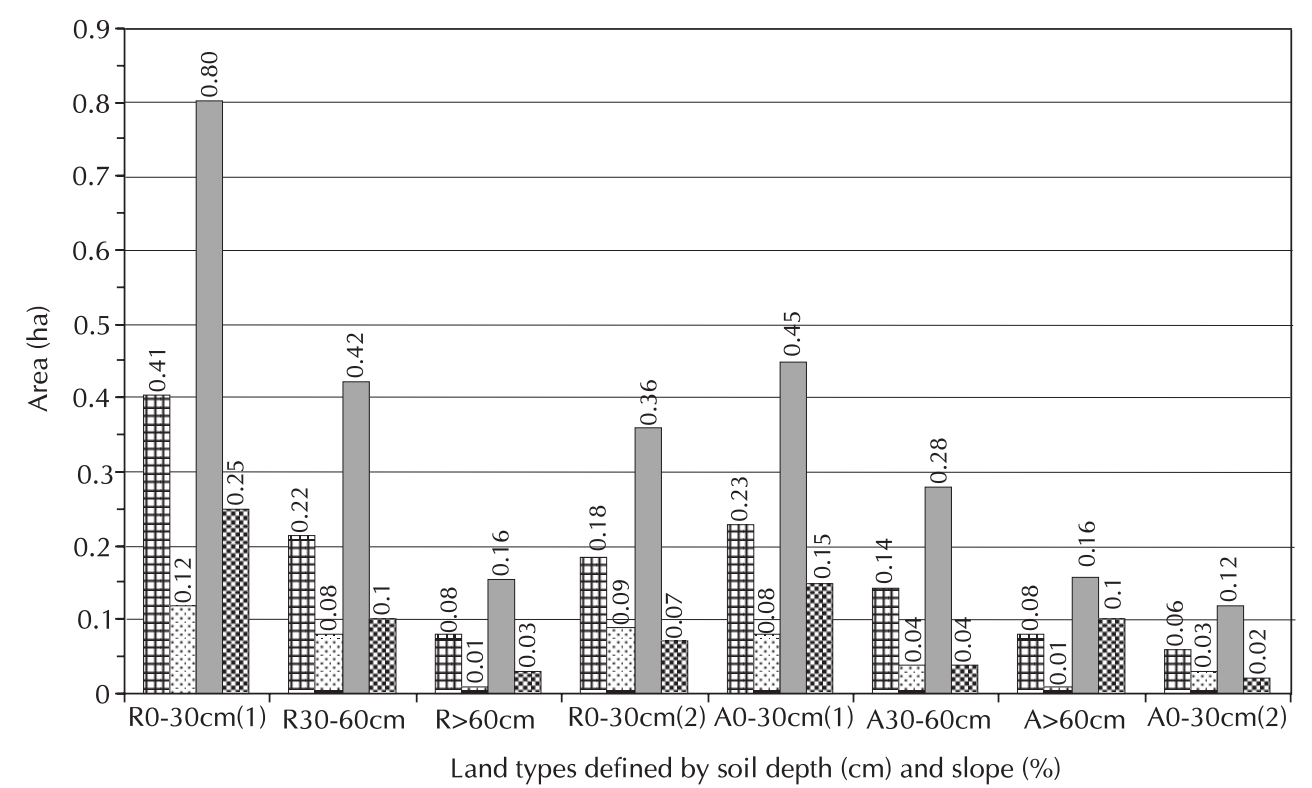

囲 0-ox total area 0-ox initial conservation $\square$ 2-ox total area 2-ox initial conservation

Fig. 12.1. Cultivable land and initial level of conservation by household group and land type (as defined in Table 12.3).

\section{The Bioeconomic Model}

Understanding farm households' incentives and constraints to intensification of land use, technology choice and investment behaviour, and analyses of the resulting pathways of development requires integration of biophysical and economic modelling approaches at the household level (Ruben et al., 1998). The bioeconomic model developed here uses a non-separable farm household model (de Janvry et al., 1991) as a basis. Production, consumption and investment decisions are jointly determined in each period. This results from imperfections in input and output markets that introduce divergence between selling and buying prices (price bands). In such situations, decisions are constrained by market imperfections, and household attributes and asset endowments will affect production and investment choices. The on-site costs of soil erosion and nutrient depletion are endogenous in the model and their future land productivity impacts influence the choice of land management practices. Off-site effects are not accounted for, but the model allows quantification of soil erosion and runoff that may also affect water bodies and other farmers in the vicinity.

The farm household maximises the discounted utility $(D U)$ subject to resource supply, market access and subsistence consumption constraints:

$$
D U=\sum_{t=1}^{T} U_{t}\left(1+r_{t}\right)^{-(t-1)}
$$


The utility function is specified as:

$$
U_{t}=\frac{1-\mu}{\left(\frac{F Y_{t}}{S Y_{t}}\right)^{\mu-1}}+\mu-1
$$

where $F Y_{t}$ is the full income of the household (as defined in Equation 4). $S Y_{t}$ is the subsistence (poverty line) level of full income estimated based on the annual poverty line income (Dercon and Krishnan, 1996) of Birr 528 (US\$1 = Birr 6 in 1993/94) per consumer unit (CU) and minimum consumption of leisure time in the area. The utility function $\left(U_{t}\right)$ has an elasticity of marginal utility of income (also called flexibility of money) equal to $-\mu$. The curvature of the utility function has a relative risk aversion coefficient equal to $\mu$. The marginal utility of income estimated for different countries ranges from -3 at low levels of per capita income to -1.1 at higher levels (Bieri and de Janvry, 1972). A value of $-\mu=3$ was used. As defined, the utility function attains a negative value when income is less than subsistence, a zero value when income is just equal to subsistence, and a positive value when income is higher than subsistence consumption. This provides a good indicator of the welfare impacts of conservation investments

Based on Holden et al. (1998) the rate of discount $r$ is endogenous in the model and is determined by the level of income and asset endowments:

$$
\begin{aligned}
& r_{t}=\frac{F V_{t+1}}{P V_{t}}-1 \\
& P V_{t}=z+\beta\left\{\frac{\left(F Y_{t}-\Sigma_{s} w_{s t} L_{s t}^{c}\right)}{Y C U_{t}}\right\}
\end{aligned}
$$

where $P V_{t}$ is the present value equivalent of future income $\left(F V_{t}\right)$ the household is willing to accept instead of waiting for one more year. The $P V_{t}$ is assumed to be dependent on the level of income per $\mathrm{CU}$ in each period $\left(Y C U_{t}\right)$; the value of $\beta$ is determined from an econometric model estimated for farmers in Ethiopia (Holden et al., 1998). The upper and lower bounds of $P V_{t}$ are estimated based on survey data and the highest and lowest discount rates found for households. Based on average incomes, the value of $z$ is calibrated at levels consistent with the highest and lowest bounds for different household groups. In this way, an increase in household income increases the present value equivalent of future income, and reduces the rate of discount, indicating the household's ability to trade-off current consumption to improve future livelihoods. If the income level falls, the opposite would occur. The effects on technology choice and investments are estimated by solving the model for upper and lower bounds on the discount rates. 
Household full income is given by:

$$
\begin{aligned}
& F Y_{t}=\sum_{g=1}^{G} \sum_{c=1}^{C} A_{c g t}\left\{p_{c t} y_{c g t}\left(x_{c g t}\right)-\sum_{i=1}^{I} e_{i c g t} x_{i c g t}\right\}+ \\
& \sum_{V=1}^{V} L_{v t}\left\{p_{v t} y_{v t}\left(x_{v t}\right)-\sum_{i=1}^{I} e_{i v t} x_{i v t}\right\}+\sum_{s}^{S} w_{s t}\left(L_{s t}^{c}+L_{s t}^{o f}\right)
\end{aligned}
$$

$A_{c g t}$ is the area of crop $c$ produced on land type $g$ in year $t . L_{v t}$ is production of units of livestock $v$ in each period. $x_{t}$ is a vector of inputs used in production of a unit of crop $c$ in land type $g$ and livestock $v$ in year $t . p$ is the per unit price of crops or livestock and $e$ is the per unit input cost. $y_{c g t}$ is the yield function for the production of crop $c$ and $y_{v t}$ is the yield function for livestock $v$. In year $t$, family home time (leisure) in each season (s) is $L_{s}^{c}$ while $w_{s}$ is the seasonal reservation wage (after transactions costs). The seasonal off-farm labour supply is $L_{s}^{o f}$.

\section{Linkages between the economic and biophysical system}

The key equations that link the biophysical system with the economic behavioural model are embedded through the production functions that include the effect of changes in soil quality. Change in the soil nutrient stock is the cumulative outcome of positive and negative processes. Use of organic and mineral fertilisers adds soil nutrients, while soil erosion depletes both rooting depth and soil nutrients. The cumulative change in the available nutrient stock affects crop yields in the following years. Depending on the cost of abating soil degradation through conservation and/or fertiliser use, this creates the economic incentive to adopt new sustainability-enhancing practices. The change in the soil nitrogen $(\mathrm{N})$ stock is given by:

$$
N_{t+1}+N_{t}-\delta\left[N_{t}-\eta\left(S E_{t}\right)\right]-\eta\left(S E_{t}\right)
$$

where $S E_{t}$ is the period $t$ rate of soil erosion, $\delta$ is the share of soil $\mathrm{N}$ mineralised in each period and $\eta$ is the $\mathrm{N}$ composition of the soil. Based on the advice of agronomists, an enrichment ratio of 2 for eroded soil and an annual mineralisation rate of $1 \%$ for soil $\mathrm{N}$ were used. The change in plant-available soil-N due to soil erosion and nutrient depletion from period to period $(d N)$ is computed as:

$$
d N=\delta\left(N_{t}-N_{t+1}\right)
$$

where $\delta$ is as defined above. The cumulative reduction in plant-available $N$ is included in the production function (Equation 7.2) to influence crop yields in each period. Since incorporating the effect of phosphorus $(\mathrm{P})$ depletion on land productivity requires additional data on $\mathrm{P}$-fixation, conversion of stabile $\mathrm{P}$ to labile $\mathrm{P}$, and the total P-stock in the soils, the model currently includes only the effects of depletion of rooting depth and soil-N on crop yields.

Crop yield $\left(y_{c g t}\right)$ for crop $c$ on land type $g$ in period $t$ is estimated in two steps. Firstly, the intercept term $\left(y^{\text {int }}\right)$ representing the depth-yield 
relationship without fertiliser use was estimated econometrically as a function of soil depth $\left(S D_{t}\right)$ and soil type $(S T)$ based on the SCRP time-series collected at the site (Shiferaw and Holden, 2001). Secondly, responses to N and $\mathrm{P}$ were estimated from Food and Agriculture Organization of the United Nations (FAO) fertiliser-response studies (Ho, 1992) and the soil productivity calculator (Aune and Lal, 1995) as a function of fertiliser nutrients and the cumulative change in the available soil-N $\left(d N_{t}\right)$. Hence, the intercept term and the yield function are given as:

$$
\begin{aligned}
& y_{c g t}^{\text {int }}=f\left(S D_{t}, S T\right) \\
& y_{c g t}=f\left(y_{c g t}^{i n t}, d N_{t}, N_{t}, P_{t}\right)
\end{aligned}
$$

where $N_{t}$ and $P_{t}$ are nitrogen and phosphorus available to plants.

The rate of soil erosion $\left(S E_{t}\right)$, and hence the change in soil depth for each land type, in each period depends on the soil type (ST), slope (SL), rainfall $(R F)$, land management or conservation technology used $(K)$, and the type of crop grown (c):

$$
S E_{t}=f\left(S T, S L, R F_{t}, K_{t}, c_{t}\right)
$$

The parameters of Equation 8 were obtained from the SCRP experiments at the site or were estimated based on plot-level survey data. In return, soil erosion affects soil depth in each period such that:

$$
S D_{t}=S D_{t-1}-\varphi S E_{t}
$$

where $\varphi$ is the conversion parameter. Hence, the soil depth trajectory depends on the initial soil depth and the cumulative level of soil erosion. Most of the model parameters were exogenously determined. These parameters include input and output prices, wage rates, seasonal working days (excluding religious holidays), population growth rate, activity-wise resource requirements, nutrient content of local foods, and household asset endowments. Given the objective function and a set of resource availability and market constraints, the model determines optimal values of variables that represent crop-livestock production, consumption and conservation investments.

\section{Other model variables and constraints}

Major activities in the model include production of six crops on eight land types with ten levels of fertiliser use [diammonium phosphate (DAP) and urea]; two land management options; two cropping seasons; consumption, storage and selling of crops; allocation of family labour (over ten seasons) for production, conservation, off-farm employment (constrained) and leisure; 
seasonal labour hiring; production, selling and consumption of livestock; buying of agricultural products for consumption; buying of livestock feed (crop residues); and constrained local markets for renting in/out land and oxen. The model constraints include limits that the use and sale of available resources (e.g. land, seeds, labour, fertiliser, oxen power, food, animal feed and liquidity) could not exceed total household endowments:

$$
\begin{aligned}
& \Phi A_{t}-X_{t}^{b} \leq X_{t}^{w} \\
& X_{t}^{s} \leq X_{t}^{w}-\Phi^{w} A_{t}
\end{aligned}
$$

where $A_{t}$ is a vector of the level of activity, $\Phi$ is a vector of total and $\Phi^{w}$ owned resource requirement per unit of activity $A, X^{w}$ is a vector of owned resources, $X^{b}$ is a vector of bought (hired) resources, and $X^{s}$ is a vector of sold or outrented resources. Available resource supplies can be increased through participation in markets (10.1). According to local norms, the model assumes that labour may be hired in cash, in kind (fixed output) or in exchange for traction power. Land can be in-rented in cash or in kind (fixed output), the price depending on its quality. The model also allows in-renting or out-renting of oxen in exchange for labour or cash. When the family resource stock is nil (e.g. fertiliser), all the demand will be met from markets. When markets exist, resources not used in production can also be sold, but the amount used and sold cannot exceed available supplies (10.2). The overall cash and credit constraint is specified as:

$$
P_{t}^{b} X_{t}^{b}+(1+\gamma) X_{t-1}^{c r}-P^{s} X_{t}^{s} \leq X_{t}^{l q}+X_{t}^{c r}
$$

where $P^{b}$ is the buying and $P^{s}$ selling price, $X^{l q}$ liquidity at hand and $X^{c r}$ is the level of credit (with interest rate $\gamma$ ) received during each period. When liquidity is non-existent, all purchases will be financed from available credit and sale of resources (inputs or products). When credit is not available, cash expenditures cannot exceed cash income from sales. The interest and the principal from the credit used in the previous period $\left[(1+\gamma) X_{t-1}^{c r}\right]$ should be paid back during the next period. Consumption requirements were specified as:

$$
\lambda\left[X_{t}^{w}+X_{t}^{b}\right] \geq \Omega
$$

where $\lambda$ is a vector of nutrient composition of owned $\left(X_{t}^{w}\right)$ and purchased $\left(X_{t}^{b}\right)$ foods and $\Omega$ is the biologically determined nutritional requirement for carbohydrates, fats and proteins. Households can use markets to meet resource demand (10.1) and consumption requirements (12) but buying activities for inputs and products include a price band of $5-10 \%$ over farmgate selling prices. All purchases are also subject to a cash constraint given in Equation 11. The model also allows for the import of commonly consumed crops not grown in the area. Taste and food diversity constraints reflecting observed consumption choices were also imposed. Consumption of grains could also include savings from previous production. The consumption requirements depend on family size and CUs. The production balance in 
each year for consumed products is given as:

$$
Q_{\text {cons }}+Q_{\text {seed }}+Q_{\text {sold }}+Q_{\text {stored }}=Q_{\text {Tot }}
$$

This indicates that the total production is consumed $\left(Q_{\text {cons }}\right)$, used as seed $\left(Q_{\text {seed }}\right)$, sold $\left(Q_{\text {sold }}\right)$ and/or stored $\left(Q_{\text {stored }}\right)$ for subsequent periods. Likewise, family labour is allocated to different activities seasonally as follows:

$$
L_{s t}^{c}=L_{s t}-\left(L_{s t}^{f}+L_{s t}^{o f}\right)
$$

This shows that family labour in year $t$ and season $s\left(L_{s t}\right)$ is used onfarm $\left(L_{s t}^{f}\right)$, off-farm $\left(L_{s t}^{o f}\right)$, and the residual consumed as leisure $\left(L_{s t}^{c}\right)$. Offfarm employment is constrained to average levels estimated from the survey for different household groups. Other constraints include restrictions on crop rotations such that cereals follow land sown to legumes in the previous period. Accounting equations include land, crop and technology-specific soil erosion; cumulative changes in soil depth; and cumulative changes in conservation investments. Changes in the stock of animals was specified for each type as:

$$
L V_{t}=(1-\theta-m) L V_{t-1}+L V R_{t-1}+L V_{t}^{b}-L V_{t}^{s}
$$

where $L V_{t}$ is adult livestock in period $t, \theta$ is the culling rate, $m$ is the mortality rate, $L V_{t-1}$ is the closing stock in the previous period, $L V R_{t-1}$ is young stock of certain ages in the previous period reared into adult animals in period $t$ and $L V^{b}$ and $L V^{s}$ are animals bought and sold during the period. Production and rearing of young stock is given as:

$$
(1-m) k L V_{t}^{f}=L V R_{t}+L V R_{t}^{c}-L V R_{t}^{s}
$$

where $L V_{t}^{f}$ is female animals of reproductive age, and $k$ is the litter size per reproductive female. The total number of newborns, adjusted by the mortality rates $(m)$, is reared $(L V R)$, consumed $\left(L V R^{c}\right)$ or sold $\left(L V R^{s}\right)$ within the year. The detailed structure of the model is presented in Holden and Shiferaw (2004).

\section{Scenarios for analysis of technology and policy impacts}

The bioeconomic model was used to simulate the adoption and potential impact of two types of land and water management options introduced into the area by the SCRP and the Ministry of Agriculture. These technologies were developed based on graded soil-stone bunds to enhance water infiltration, and drainage of excess water, and to reduce soil erosion. Farmers indicated that the structures occupy productive land and reduce yields in the initial period, especially on steeper slopes. In order to assess how this will affect adoption of these technologies, we specified two stylised versions of the technology. Type I is when the initial effect of area loss from adoption of the conservation methods is negligible and short-term yields are unaffected, and Type II is when loss of productive land and other undesirable effects may reduce initial yields with conservation by $5-10 \%$ depending on the slope. The Type I situation may arise if conservation improves soil fertility or raises 
relative returns to fertiliser use and offsets the negative effect of area loss. The Type II situation may arise when positive effects are negligible or when negative outcomes are dominant. Both are very likely and valid scenarios. Even if Type II conservation has a short-term yield penalty, it could still be attractive in the long term as crop yields exceed those without conservation. The length of time needed for this to occur will depend on the interaction between existing soil depth, the level of soil erosion and the type of crop grown. However, with a positive discount rate, delayed benefits may not create incentives for small-scale farmers to adopt these technologies. The model captures these relationships and impacts on welfare outcomes and the condition of the resource base.

Furthermore, depending on slope, adoption of these technologies is estimated to require 100-120 working days/ha while annual maintenance requires 15-20 days/ha. The model also allows removal of some of the existing conservation structures installed through food-for-work programmes and mandatory polices of the past. Figure 12.1 shows the area of land under different categories and the existing level of conservation in the initial year. Removal is assumed to require $25 \%$ of the labour need for construction. The decision to remove will depend on the availability and opportunity cost of family labour, the ability to pay for hired labour, the scarcity of land, and the expected returns from removal or maintenance of the structures. The expected return will in turn depend on the crop grown, the soil type and the slope of the land.

The two variants of the technology (Type I and II) are nested in the model for two household groups: without oxen (poor households), and with a pair of oxen (less-poor households). Since farm and non-farm employment opportunities are limited, it is hypothesised that the relative availability of land and oxen assets will be crucial for household welfare while the relative abundance of family workforce relative to land will contribute to increased conservation investments. In order to capture this complex relationship, each of the two household groups are further disaggregated into two sub-groups depending on the relative endowment of land and labour resources within the household at the initial period. Hence, four modelling scenarios are developed: without oxen and land-scarce, without oxen and land-abundant, with two oxen and

Table 12.4. Household sizes in the selected scenarios at the initial period.

\begin{tabular}{|c|c|c|c|c|}
\hline & \multicolumn{2}{|c|}{ Households with two oxen } & \multicolumn{2}{|c|}{ Households without oxen } \\
\hline & Land-scarce $^{a}$ & Land-abundant ${ }^{\mathrm{b}}$ & Land-scarce $^{b}$ & Land-abundant ${ }^{\mathrm{a}}$ \\
\hline Family size & 7.2 & 4.2 & 7.2 & 2.8 \\
\hline Worker units & 4.0 & 1.5 & 4.0 & 1.5 \\
\hline Consumers units (CU) & 6.6 & 3.0 & 6.6 & 2.6 \\
\hline Land (Regosols) ${ }^{c}$ & 6.98 & 6.98 & 3.52 & 3.52 \\
\hline Land (Andosols) & 4.02 & 4.02 & 2.03 & 2.03 \\
\hline Total farm size & 11.00 & 11.00 & 5.55 & 5.55 \\
\hline Total farm size per capita & 1.53 & 2.62 & 0.77 & 1.98 \\
\hline
\end{tabular}

a These are average values for the group from the study area.

${ }^{\mathrm{b}}$ Labour endowments are adjusted to explore the effect of changes in land-labour ratios.

c The land areas are in Timad (approximately $0.25 \mathrm{ha}$ ). 
land-scare, and with two oxen and land-abundant. Table 12.4 shows the major attributes and cumulative asset endowments of these four household groups. The model uses the detailed land classification shown in Table 12.3. The multi-period model, written in GAMS, is solved for $t=5$ years. The 5year model has about 25,700 variables and solves within 1-2 hours using present-day Pentium- 4 computers.

\section{Simulation Results}

As stated earlier, the bioeconomic model allows a simultaneous evaluation of the level of technology adoption and the associated effects on productivity, human welfare and sustainability. The optimised model provides extensive results on the crop-livestock economy, marketed surplus, conservation investments, consumption levels and changes in soil depth and soil erosion. The main focus here is on adoption of NRM technologies and productivity and environmental impacts. The differential conservation adoption patterns and the resulting livelihood and resource conservation outcomes for the different household groups are discussed. The level of conservation investments is reported for the different land types at varying endogenous rates of discount.

\section{Adoption of NRM technologies}

\section{Households with a pair of oxen}

Boserup (1965) hypothesised that intensification of land use and investments to enhance land productivity will be limited when land is more abundant than labour. This suggests that labour-scarce families with large farms will have lower incentives to increase the intensity of labour use and other inputs per unit of land to enhance its productivity. This may particularly be the case if land markets are imperfect and surplus land cannot be sold or leased out to others. These simulations also indicate that when land is more abundant than labour, the land users lack sufficient incentives to make significant erosion control investments (see Tables 12.5 and 12.6). The level of investment in conservation and soil fertility management is much larger for land-scarce households than for land-abundant households. When conservation does not incur a short-term yield penalty (Type I), the land-scarce households make significant conservation investments in all land types except the steep slopes that are mainly used for grazing. While labour-scarce households adopt conservation practices on a maximum of one-third of the different land types, the land-scarce (labour-rich) households are able to adopt conservation on up to $97 \%$ of the area of some land types (Table 12.5).

Compared to the land-scarce household, the short-term welfare impact of soil degradation in terms of future productivity decline is relatively less for the land-abundant household. Even if soil erosion increases on untreated lands, households with relatively abundant land will have enough land to 


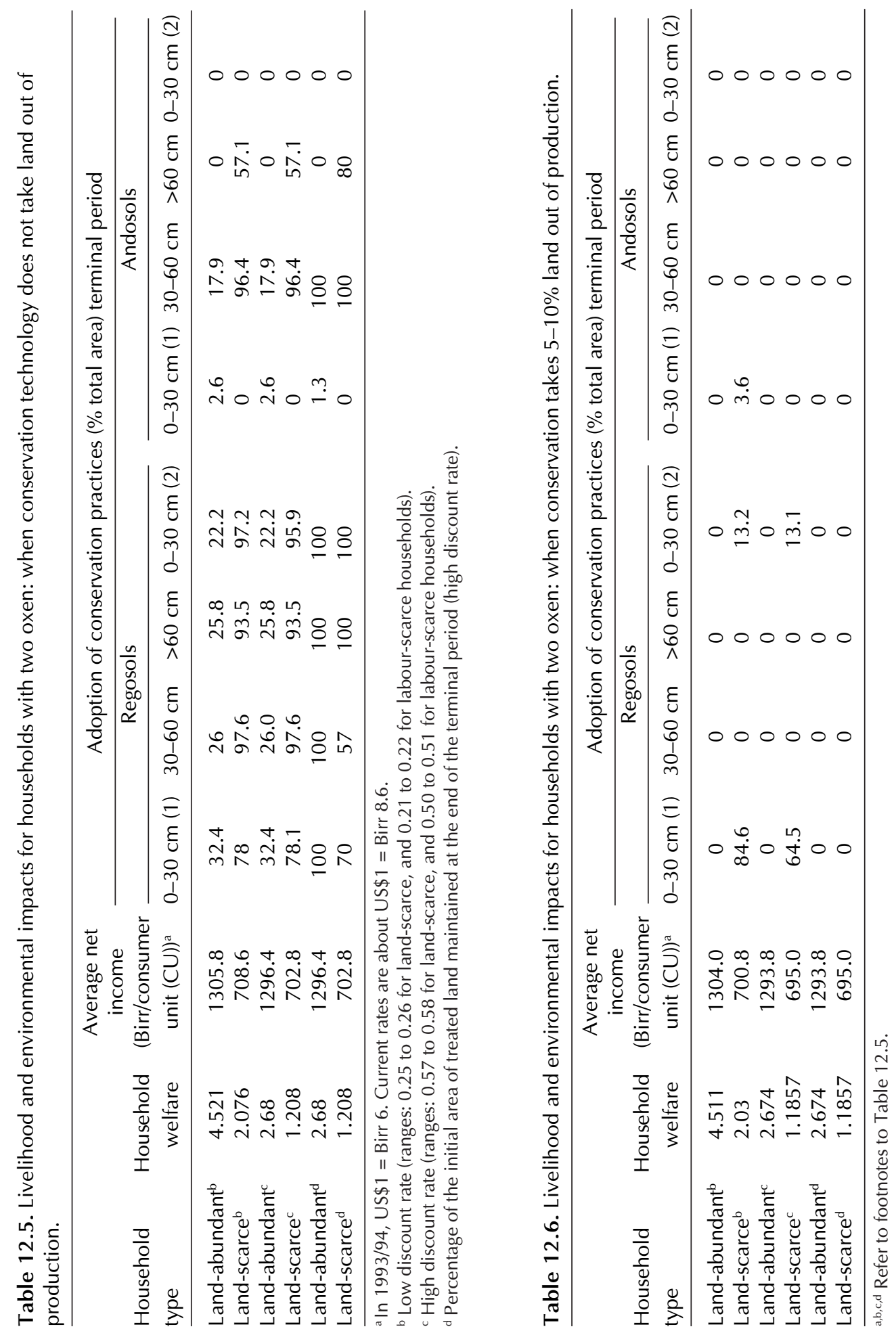


maintain their current welfare levels. The limited effect of degradation on their welfare reduces the incentive to mitigate the externality, especially when the rental value of land does not increase with conservation investments. A labour-scarce household with relatively abundant land will cultivate some of the land and rent out the rest. The incentive to treat out-rented land with conservation investments depends on the expected economic benefits. It was found that village land rentals markets do not reflect the value of conservation investments but do reflect land quality aspects that affect its productivity. This means that land of the same quality (whether or not treated with conservation measures) has the same rental value and that there is no short-term economic incentive for the land 'owner' to invest in conservation. Therefore the model does not choose conservation on out-rented plots. This result would have changed if the rental value of land decreases due to soil degradation as in share-tenancy arrangements. Future work may need to assess such effects. Shortage of labour relative to land also means that the labour-scarce household may have to hire-in labour in order to install labour-intensive conservation investments. The cumulative effect of scarcity of labour and land abundance is lower soil conservation effort for the labour-scarce household.

For Type I conservation technologies, it was also found that the labourscarce households maintain much of the initial conservation (except those on deep soils where erosion effects are low or on marginal lands used for grazing) previously installed on their lands through programme benefits, while the land-scarce households dismantle most of the initial conservation (Table 12.5).

The investment gap and resulting impacts on the welfare of households and the resource base are even more pronounced for Type II conservation technologies that could take some land out of production and reduce initial crop yields (Table 12.6). In this case, both types of households quickly dismantle the existing conservation structures, especially in plots where the perceived risk of erosion is low. However, land-scarce households eventually install them on shallow soils where their effect on productivity is high and hence conservation benefits are large (Table 12.6). The re-investment on some plots seems to occur in later years as welfare levels improve from livestock production and storage of surplus grains. This may not be the case if risk were to be included in the model (Holden and Shiferaw, 2004). Compared to Type I technology, in the 5-year period considered here the overall conservation investment is highly reduced. The households may not, however, have removed the initial conservation investments if a longer planning horizon and a lower discount rate were used (although this may not be a realistic assumption). Moreover, since the discount rates are high and a longer time period is required for conservation benefits to have appreciable effects on productivity, the upper and lower bound discount rates in both cases did not show significant differences in household conservation investments. 

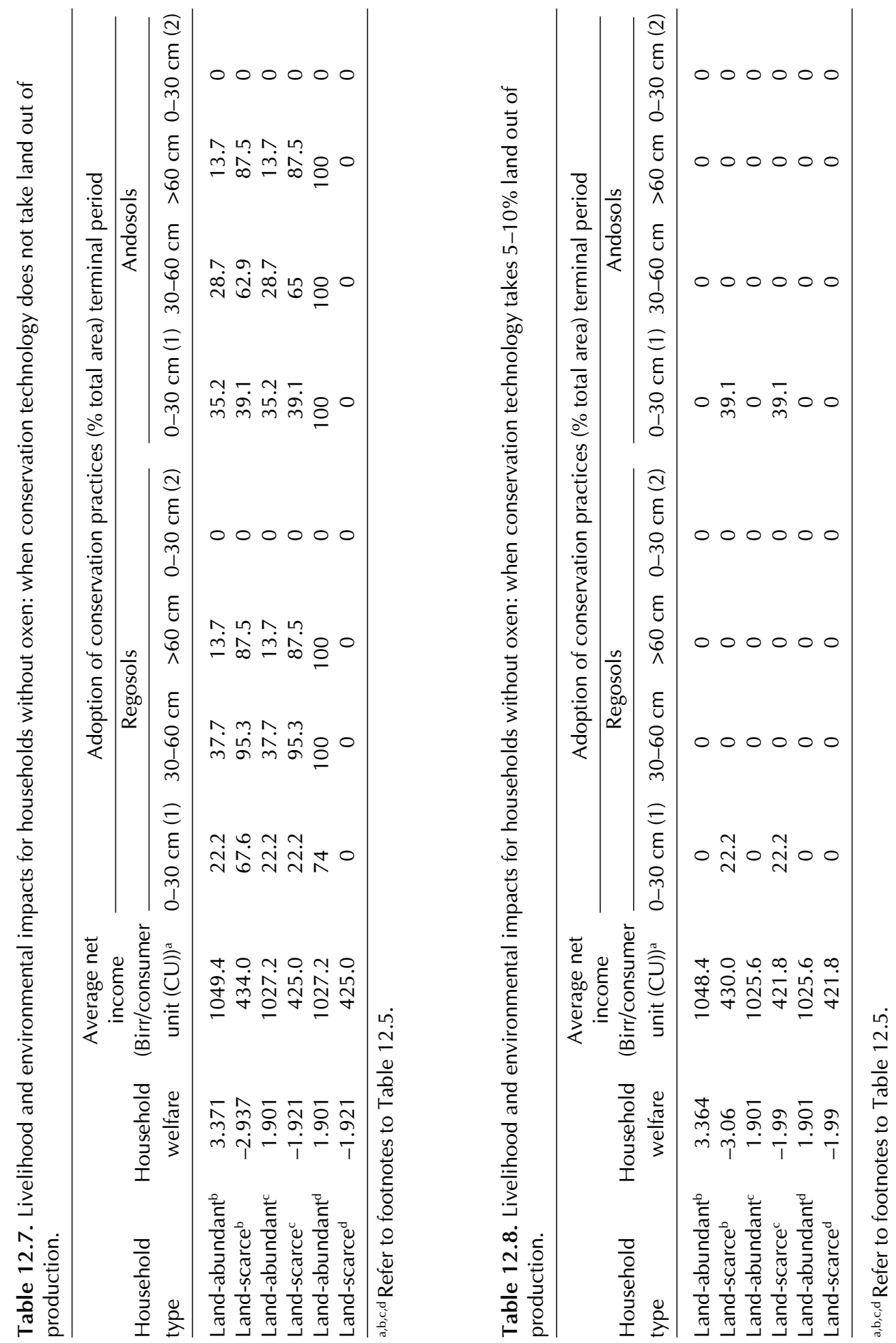


\section{Households without oxen}

The corresponding results for the two household groups without oxen are presented in Tables 12.7 and 12.8. Under Type I technology, it was also found that the relative abundance of labour and scarcity of land improves the likelihood of sustainability investments. However, compared to households with a pair of oxen, the level of adoption of conservation is reduced, so the productivity and sustainability impacts of improved NRM options are relatively diminished. When the household is poor both in oxen and land, large family sizes put high pressure on the household's ability to meet subsistence needs. While the lack of oxen for ploughing compels the household to rent out land, imperfections in food markets and the presence of price bands work in the opposite direction. Under pressure from conflicting market influences, the household in-rents some traction power to grow a portion of its subsistence needs and rents outs some of its land. It spends about $15 \%$ of the available working time on hiring-in oxen for traction. However, meeting the consumption requirements of a large household becomes difficult unless the surplus labour finds some employment off-farm; the household allocates the allowable maximum $25 \%$ of the available labour time in activities that include petty trade and employment within and outside the village to earn supplemental income. If the labour market is missing, the model becomes infeasible, indicating that the household is simply unable to meet its subsistence needs unless external assistance (e.g. food aid) is provided. If sufficient off-farm employment is available, labour-rich households without oxen are more likely to reduce on-farm labour and work more off-farm, which may further depress investment in conservation. When off-farm employment is limited (as in this case) the household invests labour to install Type I conservation technologies (see Table 12.7). These investments occur on prime agricultural land where conservation benefits are high while steep slopes $[\mathrm{R} 0-30 \mathrm{~cm}(2)$ and $\mathrm{A} 0-30 \mathrm{~cm}(2)]$, mainly used as pasture for livestock, are left without conservation.

When thehousehold is poor in bothoxen and labour, therelativeabundance of land and shortage of labour discourages conservation investments. The household will hire-in some traction power and labour seasonally to produce part of its subsistence, but will rent out the remaining land annually without conservation. Since fewer workers also mean smaller CUs, the household with relatively abundant land is able to meet its subsistence needs although it invests relatively less in conservation practices. Imperfections in land, oxen, labour and credit markets jointly constrain labour- and oxen-poor households from investing in conservation while compelling them to rent out part of their land assets to labour- and oxen-rich households within the village. If the revenue from land rentals declines because of soil degradation (i.e. rental markets reflect the value of soil conservation), and if labour, oxen and credit markets function well, the labour-scarce household is likely to use much of its land for itself or rent out it after undertaking conservation investments. Currently there is no credit for conservation, and fertiliser credit is minimal and unreliable (see below on the effect of credit). Both selling and long-term leasing of land are illegal in Ethiopia. Along with productivity- 
enhancing technical change, lifting such restrictions could enhance the value of land and the efficiency of land rental markets. Empirical evidence in Africa and elsewhere shows that under favourable policies (e.g. secure land rights) and market conditions, and when sustainability investments provide high relative returns, smallholders are unlikely to ignore the sustainability impacts of current land-use decisions (user costs) (Tiffen et al., 1994; Heath and Binswanger, 1996; Templeton and Scherr, 1999; Holden et al., 2001). These are important policy constraints that need to be tackled to encourage land investments in Ethiopia.

As expected, labour-scarce households maintain more of the initial conservation measures than land-scarce households. The situation is very different for Type II conservation technologies (Table 12.8). In this case, both households remove the conservation structures on their plots. Only landscarce and labour-endowed households allocate some labour for conservation. Hence, the level of conservation adoption is minimal and the attained impact on the quality of the resource base is very limited mainly because exploitative traditional agricultural practices with high levels of soil erosion (up to 40 t/ha) continue (Shiferaw and Holden, 2001).

\section{Economic and sustainability impacts}

The above results have clearly shown the roles of land and labour scarcity in household conservation investment decisions. It was hypothesised that the endowment of traction power and farmland will largely determine the welfare impacts of new technologies. Households that are poor in land and oxen can therefore be expected to attain the lowest level of welfare. The discounted utility (welfare) and the average net income per CU for the different scenarios are presented in Tables 12.5-12.8. The results show that adoption of NRM practices is very minimal for Type II technologies. This means that the farmer will largely use existing practices and the welfare and environmental impacts from such interventions will be minimal. Comparison of the welfare and income differences under Type I and II technologies can therefore reveal the economic impacts associated with adoption of improved NRM practices. For example, the land-abundant household attains a welfare level of 4.521 under Type I, which declines to 4.511 under Type II where no adoption has occurred, representing a discounted welfare gain in 5 years of $0.22 \%$. Similarly the average net annual income per CU has shown a slight increase of about Birr $2(0.15 \%)$, which amounts to about Birr 10 in 5 years. These are direct benefits associated with the reduction in soil degradation from adoption of the conservation technology. It is to be noted that the best NRM technology simulated (Type I) does not enhance yield; it only reduces soil erosion while yields remain unchanged in the initial years. The economic gain would have been more pronounced had the NRM technology also contributed to growth in crop yields. Moreover, in all the scenarios simulated, the better-off households with two oxen attain the poverty line level of welfare $\left(U_{t}>0\right.$ and $\left.D U>0\right)$ under both technology alternatives. Oxen- 


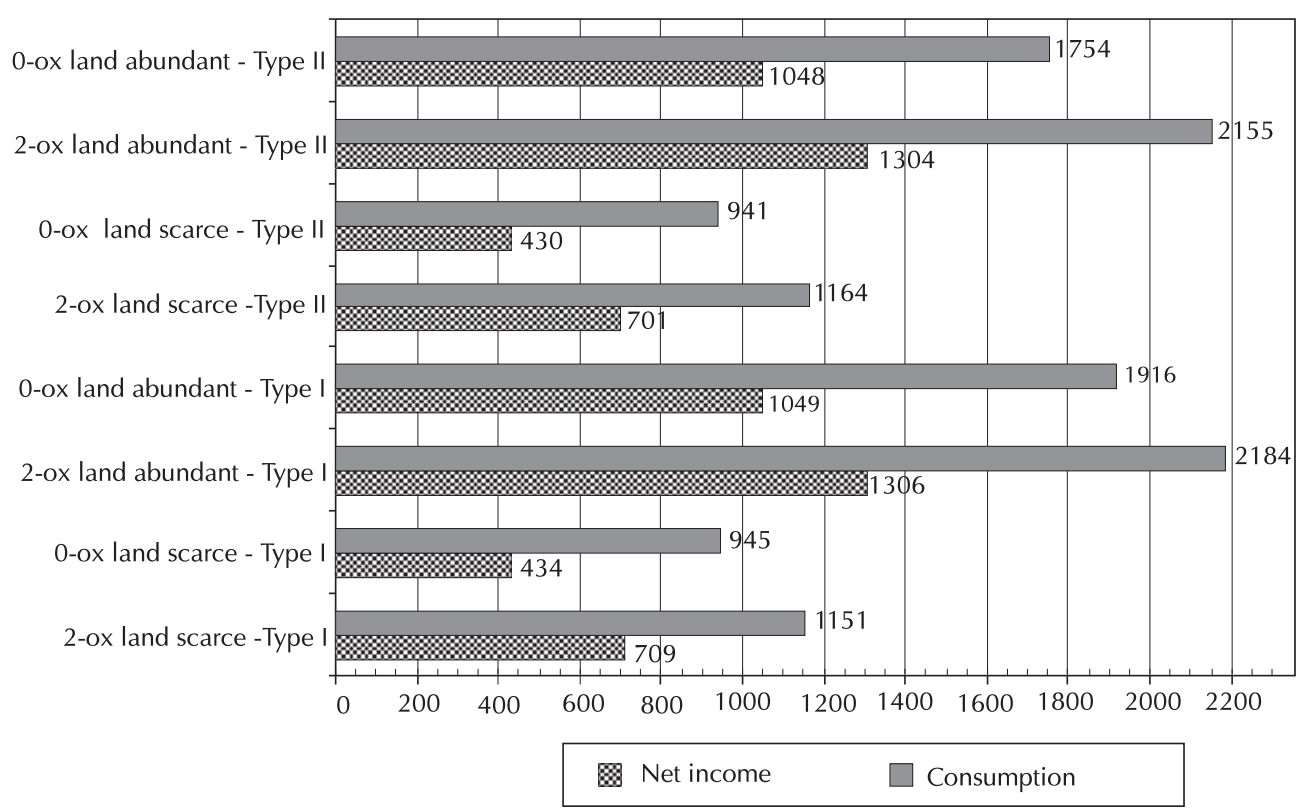

Fig. 12.2. Average annual net income (Birr) and consumption (kcal) per consumer unit by household group (US\$1 = Birr 6 in 1993/94).

owning and land-rich households with fewer consumers attain the highest level of welfare. Households without oxen attain the poverty-line welfare level only when land is not scarce and the number of consumers is limited. A combination of land and oxen poverty along with insufficient off-farm employment opportunities makes the household unable to attain the povertyline full income. Hence, these households are unable to escape poverty $\left(U_{t}<0\right)$ even when Type I conservation is used. This probably explains why many poor households in the area also have small-sized families.

The income and consumption outcomes (at low discount rates) are depicted in Fig. 12.2. Using the annual poverty line income of Birr 528/CU and subsistence calorie requirement of $840 \mathrm{kcal} / \mathrm{CU}$, the results show that all household groups attain the subsistence level of consumption but not the poverty-line net income. Land-scarce households without oxen fall far short of this level of income even though they meet their subsistence level of calorie consumption.

It will be useful to assess the level of economic gain from adoption of improved conservation practices. The gain in household net income attained per unit of land area conserved can be estimated from comparison of the net income with and without adoption of Type I technologies. For example, the average household annual net income for land-scarce and two-oxen households with adoption of Type I technologies is about Birr 51 higher than that without adoption. This amounts to about Birr 36/ha/year of conserved land. If irreversibility in soil degradation is assumed, the perpetual on-site net gain from adoption of conservation practices amounts to Birr 72 to 180/ha 


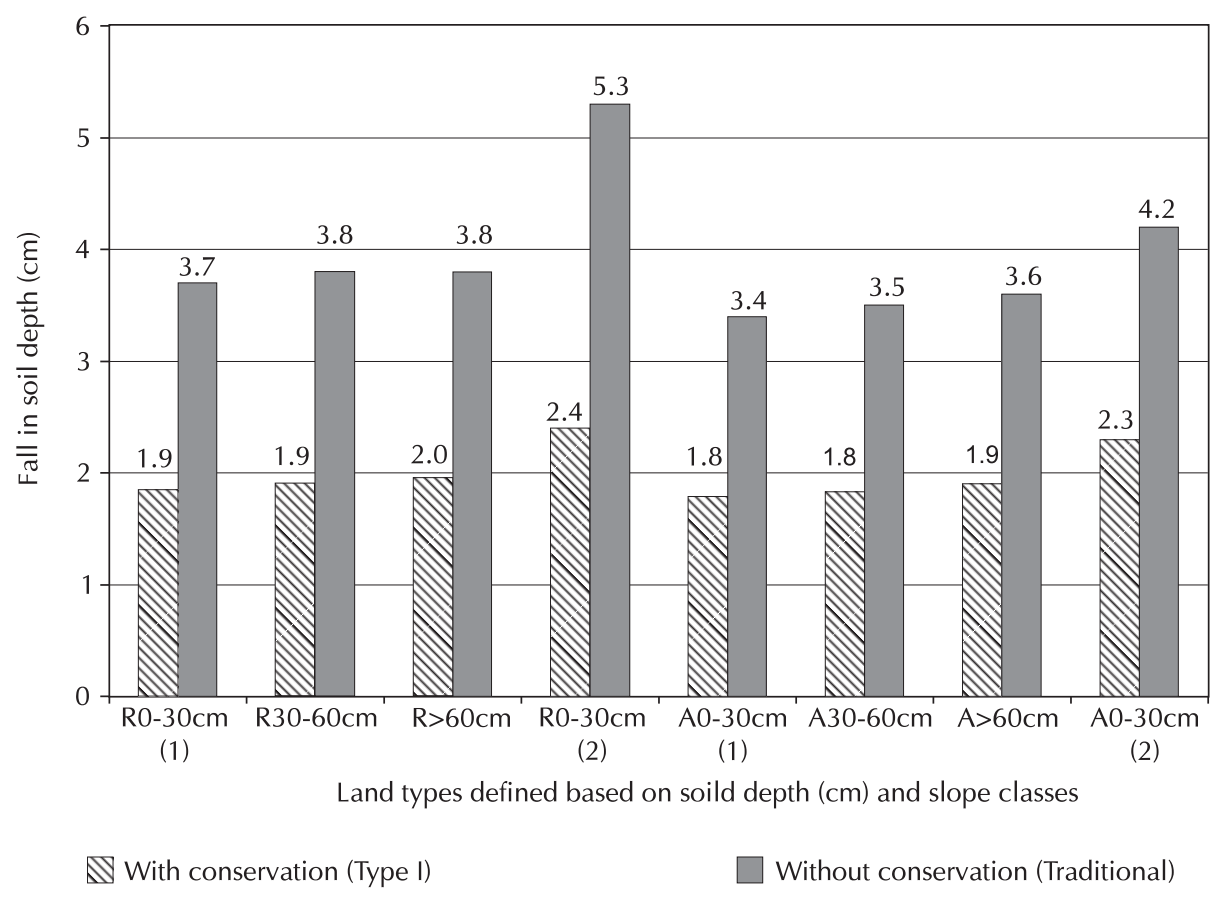

Fig. 12.3. Reduction in soil depth in 10 years: land-scarce 2-ox household (land types as defined in Table 12.3).

using the farmer's high (50\%) and low (20\%) discount rates. Adoption of high-yielding varieties and other options is likely to increase the net farmer benefits from conservation.

In order to show the long-term environmental or sustainability impacts of adopting improved management practices, the model was solved for a planning horizon of 10 years under Type I and traditional practices. The results are shown in Fig. 12.3. The fall in soil depth under Type I conservation technology is about half of that under traditional management. Depending on the soil and land type, soil depth declines by about $1.8-2.5 \mathrm{~cm}$ with conservation, but this increases to 3.2 to $5.4 \mathrm{~cm}$ under traditional management. As was shown in Equation 7.2, crop yields depend on many variables including the use of organic and inorganic fertilisers. Figure 12.4 shows the effect of soil degradation on crop productivity under differing levels of fertiliser use. If farmers do not use chemical fertilisers, barley yields decline by about $175 \mathrm{~kg} /$ ha without conservation (No Cons), while this loss falls to less than $50 \mathrm{~kg} / \mathrm{ha}$ with conservation (Cons). This indicates that, depending on the relative returns, farmers have the option of using fertilisers to replace lost nutrients or of investing in conservation practices to mitigate the effect of soil degradation. Policies for fertiliser or conservation subsidies have been used to achieve productivity and/or sustainability objectives. Since fertiliser price subsidies are no longer popular policy options, it could be useful to investigate how the credit constraint might affect farmers' conservation choices. This is explored further in the following section. 


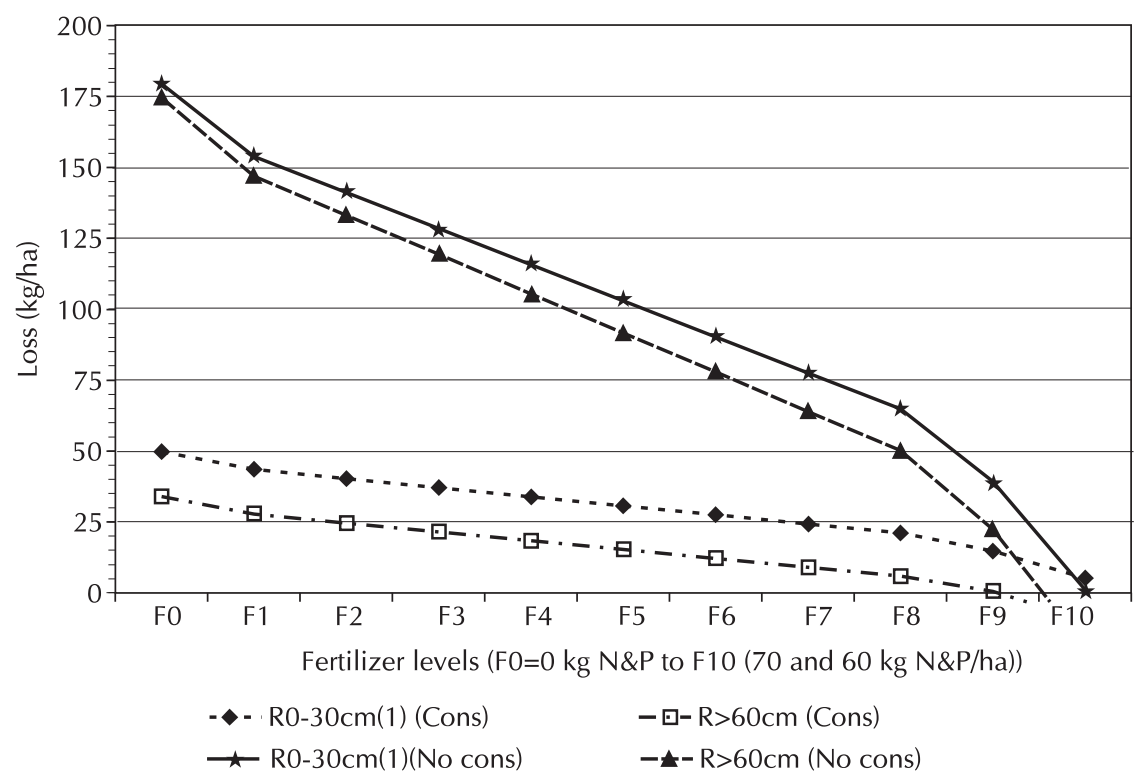

Fig. 12.4. Fertiliser use and decline in barley (Meher season) yields in 10 years under alternative land management practices (Type I vs. traditional).

\section{Effect of credit for fertiliser}

As discussed earlier, credit was not included in the base model presented thus far. What happens if the Ethiopian government increases allocation of credit for conservation and production purposes in the future? Availability of credit and fertiliser use are critical ingredients for stimulating adoption of improved technologies. Several earlier studies have shown that subsidised credit may increase fertiliser use (especially when profitable varieties are available) and may discourage investment in soil conservation (Shiferaw et al., 2001; Holden and Shiferaw, 2004). When cheap credit is available, high levels of fertiliser use can easily replace lost nutrients and reduce the need for soil conservation. The same effects can be expected from fertiliser price subsidies. As Fig. 12.4 shows, under high levels of fertiliser use, the relative productivity benefits of conservation disappear and crop yields will be similar to those without conservation. We find that for credit-constrained households, increased availability of input credit could discourage investment in conservation. This is demonstrated using results for the poor and land-scarce household group (Table 12.9). As the availability of input credit improves, the level of conservation investment declines progressively, even when Type I conservation technology is available. With Type II conservation technologies, access to credit seems to entirely wipe out all the incentives for conservation. In this case fertiliser use becomes more economical than soil conservation to counter soil degradation. The decrease in sustainability investments occurs while short-term welfare improves because of increased fertiliser use and improved land productivity. It is not clear, however, for how long fertilisers 


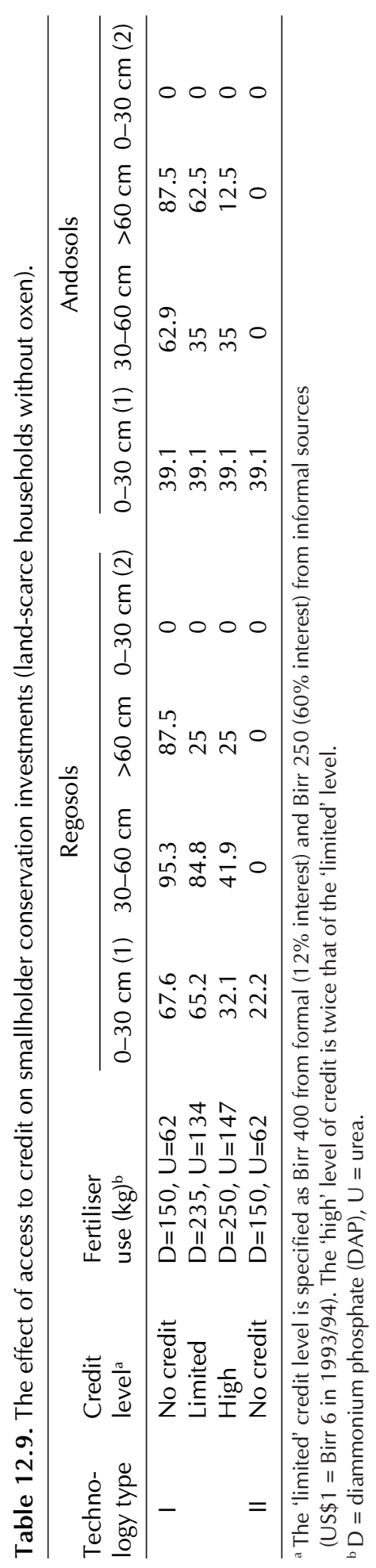


can be used to mitigate the effect of soil degradation. Agronomists argue that a minimum soil depth is essential for crop production and that once soil erosion reduces the rooting depth below a given threshold level, the marginal productivity of fertiliser use may decline. This indicates that as soil degradation increases, more fertiliser may be required to compensate for losses and to sustain crop productivity. This trade-off could be tackled through interlinkage of credit supply with conservation requirements (Holden and Shiferaw, 2004), a policy that could foster win-win economic and environmental outcomes.

\section{Conclusions and Policy Implications}

In resource-poor regions with high population pressure, sustainable use of land and other resources has become an important policy and development problem. Improved NRM interventions are important to reverse soil degradation and sustain agricultural productivity. Several recent studies have posited a nexus between poverty and the ability to undertake sustainability investments, especially when markets are imperfect. Bioeconomic models that interlink biophysical information with behavioural economic models at different spatial scales in a dynamic perspective are most suited to the analysis of NRM impacts and to determine how poverty in certain assets affects investment decisions. Using data from the Ethiopian highlands, it has been shown how a non-separable bioeconomic household model can be used to track these relationships and impacts, and how the effect of technology and policy changes affecting NRM can be evaluated simultaneously in terms of economic efficiency (the incentive to adopt the technology), welfare (poverty effects) and sustainability (resource conditions). The model is formulated for four stylised household groups and captures production, biophysical diversity and market conditions in the area. The results show that when land is relatively abundant, households are unlikely to carry out labour-intensive conservation investments. An increase in family labour coupled with scarcity of land, however, increases the incentive to invest in conservation, especially when opportunities for off-farm employment are limited and profitable conservation technologies are available. In this case, higher adoption of resource management practices leads to positive impacts on household welfare and sustainability of resource use.

It is also found that poverty in labour and traction power forces households to rent out land to other relatively better-off households. Under the existing system of usufruct rights to land in Ethiopia, sustainability investments that do not affect short-term crop yields do not affect the rental value of land. In this case, the oxen- or labour-poor households rent out land without conservation because the returns from renting are the same. This points to the need for new policies and interventions that would improve the efficiency and effectiveness of land rental markets and create incentives for land users to consider the future productivity impacts of current land-use decisions (user costs). 
The economic incentive to invest in conservation drastically decreases when the new technologies increase scarcity of land and decrease crop yields in the short term (Type II). This scenario seems to explain the extensive removal in the study area of conservation measures introduced in the past. Unfortunately, better options that provide short-term benefits to the poor are rarely available and the only reasonable way to encourage investments in such practices is to provide some targeted subsidies (e.g. cost-sharing). However, when farmers are able to perceive the consequences of soil degradation and use-rights are secure, they are able to adopt Type I conservation technologies without additional incentives. Only labour-scarce households and those without the necessary traction power are unable to make significant investments due either to the relative abundance of land or to the high opportunity costs of labour.

The direct economic gains from the adoption of Type I technologies are quite modest. The average annual income gain is estimated at about Birr 36/ ha, which translates to an increase in annual income per consumer of Birr 10 in 5 years. This is partly because the nature of the technology simulated in this case does not improve yields. Higher benefits can be expected if conservation also enhances land productivity. But the low return to available conservation technologies is a major factor that makes conservation investments less attractive than competing alternatives (e.g. off-farm employment or livestock production). This suggests the need to develop NRM technologies that provide attractive economic gains along with sustainability benefits. Land-scarce households without oxen even failed to attain the poverty-line income. The level of conservation adoption and its impact is lowest for landabundant households. Adoption of conservation measures did not arrest soil degradation, but did provide substantial benefits in terms of maintaining soil depth and improved crop productivity. The decline in soil depth with conservation is half of that under traditional practices, but the yield reduction is less than one-third of that without conservation. Fertiliser use could also reduce yield losses. There is some evidence that increased fertiliser credit may substitute for conservation effort. This may require cross-compliance types of policies that link fertiliser credit with conservation requirements.

Nevertheless, evaluation of economic and environmental impacts will not be complete until the added social benefits are compared with the research and development (R\&D) costs incurred in generating and delivering these technologies on a larger scale. When these costs are low and the associated economic and sustainability benefits are high, improved social efficiency from such NRM investments can be expected.

\section{References}

Aune, J. and Lal, R. (1995) The tropical soil productivity calculator: a model for assessing effects of soil management on productivity. In: Lal, R. and Stewart, B.A. (eds) Soil Management Experimental Basis for Sustainability and Environmental Quality. CRC Press, Lewis Publishers, Boca Raton, Florida, pp. 499-520. 
Bieri, J. and de Janvry, A. (1972) Empirical Analysis of Demand under Consumer Budgeting. Gianini Foundation Monograph 30. University of California, Berkeley, California, $60 \mathrm{pp}$.

Boserup, E. (1965) The Conditions of Agricultural Growth. The Economics of Agrarian Change under Population Pressure. Earthscan Publications, London, UK, 124 pp.

Cleaver, K.M. and Schreiber, G.A. (1994) Reversing the Spiral. The Population, Agriculture and Environment Nexus in Sub-Saharan Africa. The World Bank, Washington, DC, $227 \mathrm{pp}$.

de Janvry, A., Fafchamps, M. and Sadoulet, E. (1991) Peasant household behaviour with missing markets: some paradoxes explained. Economic Journal 101, 14001417.

Dercon, S. and Krishnan, P. (1996) A consumption-based measure of poverty for rural Ethiopia in 1989 and 1994. In: Kebede, B. and Taddesse, M. (eds) The Ethiopian Economy: Poverty and Poverty Alleviation. Proceedings of the Fifth Annual Conference on the Ethiopian Economy. Addis Ababa University, Addis Ababa, Ethiopa, pp. 77-101.

Grepperud, S. (1996) Population pressure and land degradation: the case of Ethiopia. Journal of Environmental Economics and Management 30, 18-33.

Heath, J. and Binswanger, H.P. (1996) Natural resource degradation effects of poverty and population growth are largely policy induced: the case of Colombia. Environment and Development Economics 1, 64-84.

Ho, C.T. (1992) Results of NPK fertilizer trials conducted on major cereal crops by ADD/ NFIU (1988-1991). ADD/NFIU Joint Working Paper 43, Ministry of Agriculture, Addis Ababa, Ethiopia, 85 pp.

Holden, S.T. and Shiferaw, B. (2004) Land degradation, drought and food security in a less-favoured area in the Ethiopian highlands: a bioeconomic model with market imperfections. Agricultural Economics 30(1), 31-49.

Holden, S.T., Shiferaw, B. and Wik, M. (1998) Poverty, credit constraints, and time preferences: of relevance for environmental policy? Environment and Development Economics 3, 105-130.

Holden, S.T., Shiferaw, B. and Pender, J. (2001) Market imperfections and land productivity in the Ethiopian highlands. Journal of Agricultural Economics 52(3), 53-70.

Reardon, T. and Vosti, S.A. (1995) Links between rural poverty and the environment in developing countries: asset categories and investment poverty. World Development 23(9), 1495-1506.

Ruben, R., Molla, H. and Kuyvenhoven, A. (1998) Integrating agricultural research and policy analysis: analytical framework and policy applications for bioeconomic modeling. Agricultural Systems 58, 331-349.

Shiferaw, B. and Holden, S. (1998) Resource degradation and adoption of land conservation technologies in the Ethiopian highlands: A case study in Andit Tid, north Shewa. Agricultural Economics 18(3), 233-248.

Shiferaw, B. and Holden, S.T. (2001) Farm-level benefits to investments for mitigating land degradation: empirical evidence from Ethiopia. Environment and Development Economics 6, 335-358.

Shiferaw, B., Holden, S.T. and Aune, J. (2001) Population pressure and land degradation in the Ethiopian highlands: a bioeconomic model with endogenous soil degradation. In: Heerink, N., van Keulen, H. and Kuiper, M. (eds) Economic Policy Reforms and Sustainable Land Use in LDCs: Recent Advances in Quantitative Analysis. Springer-Verlag, Berlin, Germany, pp. 73-92. 
Templeton, S.R. and Scherr, S.R. (1999) Effects of demographic and related microeconomic change on land quality in hills and mountains of developing countries. World Development 27, 903-918.

Tiffen, M., Mortimore, M. and Gichuki, F. (1994) More People-Less Erosion: Environmental Recovery in Kenya. John Wiley and Sons, Chichester, UK, 311 pp.

Yohannes, G. (1989) Land-use, agricultural production and soil conservation methods in the Andit Tid Area, Shewa Region. Research Report 17. Soil Conservation Research Project, Ministry of Agriculture Soil and Water Conservation Development, Addis Ababa, Ethiopia, 151 pp. 